\title{
THE EFFECT OF JOINING ENGLISH COURSE PROGRAM TO ELEVENTH GRADE STUDENTS' ENGLISH VOCABULARY MASTERY
}

\author{
Komala Dwi Syaputri ${ }^{1}$, Rika Yeni Yustita ${ }^{2}$ \\ Dosen Universitas Bina Darma1, Mahasiswa Universitas Bina Darma ${ }^{2}$ Jalan \\ Jendral Ahmad Yani No.3 Palembang \\ Sur-el: komala_ds@binadarma.ac.id'1, rikayeni25@gmail.com²
}

\begin{abstract}
This study aimed to discover the effect of students' participation in English course program on their English vocabulary mastery. The population of this study was the eleventh grade of SMA Pusri Palembang. Indetermining the sample, the researcher used purposive sampling technique. The sample in this study was 50 students. The students were defined as students who take English course program and those who do not. In collecting the data, the researcher used mixed-method approach. The English vocabulary mastery test and questionnaire were provided to gain the data. The test was a multiple-choice form. The instruments were analyzed statistically with SPSS 24. The result of the test by conducting Mann Whitney test showed that there was a significant difference of English vocabulary mastery between both groups of students. The result of the questionnaire showed that there were any effects of participating English course program on students' English vocabulary mastery.
\end{abstract}

Keywords: Effect, English Course Program, Vocabulary Mastery

\begin{abstract}
Penelitian ini bertujuan untuk mengetahui efek dari keikutsertaan siswa di program kursus bahasa Inggris terhadap kemampuan kosakata bahasa Inggris mereka. Populasi pada penelitian ini adalah siswa kelas sebelas di SMA Pusri Palembang. Dalam menentukan sample, peneliti menggunakan teknik purposive sampling. Sample pada penelitian ini adalah 50 siswa. Siswa tersebut merupakan siswa yang mengikuti program kursus bahasa Inggris dan siswa yang tidak mengikuti program kursus bahasa Inggris. Dalam mengumpulkan data, peneliti menggunakan pendekatan mixed-method. Tes kemampuan kosakata bahasa Inggris dan kuesioner digunakan untuk memperoleh data. Tes berbentuk pilihan ganda. Instrumen penelitian dianalisis secara statistik dengan SPSS 24. Hasil tes yang diuji dengan tes Mann Whitney menunjukkan bahwa ada perbedaan signifikan pada kemampuan kosakata bahasa Inggris diantara kedua kelompok siswa. Hasil kuesioner menunjukkan bahwa ada pengaruh mengikuti program kursus bahasa Inggris terhadap kemampuan kosakata bahasa Inggris siswa.
\end{abstract}

Kata Kunci: Pengaruh, Program Kursus Bahasa Inggris, Kemampuan Kosakata

\section{INTRODUCTION}

As social beings, humans are presumed to be inseparable from communicating. Communication is the most important aspect in life. It is the act of delivering and getting information through the use of language. Hornby (2000, p.752) cited from Syaputri
(2015) explains one of the language functions that language is a system of communicationin speech and writing, and it is used by people of a particular country. When people from different countries meet, they need a language to unite them. It will be different from other languages. People need global languages to communicate among people from other countries, and one of 
the languages that can be used is English (Crystal, 2003; Nga, 2008) in Syaputri (2015).

As a global language, English is studied and utilized by a wide community from all over the world. It can be as a first, second or foreign language. In Indonesia, English as a foreign language has been supported by government to be studied through formal and non-formal education. In formal education, English has become a compulsory subject that must be studied by elementary school students to university students. Students learn English at school in carrying out the school curriculum and build their language skills towards foreign language since earlyage.

In improving the students' English mastery, students must learn several elements of English, especially vocabulary. Vocabulary is a list of words that have meaning and also as a process of knowing and understanding the meaning of words. Vocabulary is such an important task and as an important role for students to study in all language skills; speaking, listening, writing, and reading as Nation (2001) cited in Susanto (2017). It means students will be more proficient in using language if they mastervocabulary. In addition, as Wilkins (1972, p.111) in Schmitt (2010, p.3) sums up the importance of learning vocabulary that "without grammar very little can be conveyed, without vocabulary nothing can be conveyed". It means without mastering the vocabulary, students cannot reveal their ideas, emotions, and desires. It is because vocabulary is the main element for students to understand the names of things, actions, and concepts.
There are several things that must be mastered by language learners in vocabulary. According to Cameron (2001, p.78) cited in Andriani and Sriwahyuningsih (2019), vocabulary skill includes pronunciation, spelling, grammar and meaning. While Ur (1996, p.60-62) in Anisa (2011) states that some aspects that the learner should have mastered. They are pronunciation and Spelling, grammar, collocation, meaning, and word formation.

There are many types of vocabulary according to some experts. Harmer (1991, p.159) cited in Hernawati (2015) distinguishes vocabulary as active and passive vocabulary. Meanwhile, Fries (1973) as cited in Apriliyanti (2019) classifies English vocabulary or word into four types, they are content words, function words, substituted words, and distributed words. From the explanations, the researcher focused on the content words as basic vocabulary. Furthermore, it is easy to discover for senior high school students while the students are still learning words in terms of nouns, verbs, adjectives and adverbs.

Learning foreign language vocabulary is definitely not easy. Students will encounter various difficulties in learning English vocabulary. Even though students have learned English at school, sometimes the abilities or achievements of each student are different. This can happen because it is influenced by two factors, namely: (1) internal factors; and (2) external factors. Internal factors are factors that come from the individual himself including physical and non-physical aspects, while external factors are caused by any number of outside factors; it might also be included as the 
environmental factors (Slameto, 1991) in Setiyono (2016). This is the same as Khotimah (2009) cited in Sugara (2018) that there are internal and external factors in achievement vocabulary. Internal factors are intelligence, physics, talent, emotional, and discipline. While, external factors are teachers, parents, friends, family, facility, etc.

In learning English vocabulary, students can learn from other who is more competent in English subject that can help them get a better understanding. The most common way to improve the achievement and the understanding of English vocabulary is through English course program. According to Cambridge Dictionary, course is a set of classes or a plan of study on a particular subject, usually leading to an exam or qualification. This course is a place for students to gain knowledge, increase the intensity of their learning, and improve their vocational skills in learning foreign languages, especially English. The presence of English course program is also often very reliable for parents in Indonesia to solve the students' problems in learning English. By participating to this additional learning program, students are expected to be able to build and enhance their language skills especially vocabulary. They also can find their potential learning that supports their goals such as in education, career, and communication.

\section{RESEARCH METHODOLOGY}

\subsection{Research Method}

In this study, the researchers used mixedmethod design. This research design combines quantitative and qualitative methods simultaneously. The combination of quantitative and qualitative is done so that researchers can get a better understanding of the research problem (Cohen, Manion and Morrison, 2018, p.32).

There were two variables in this study, namely independent and dependent. The independent variable in this study was defined as the type of students, namely students who take English course program and those who do not. The dependent variable in this study was defined as English vocabulary mastery.

\subsection{Object of the Study}

The population of this study was the eleventh-grade students of SMA Pusri Palembang. There were six classes with a total 139 students. In determining the sample, the researcher used purposive sampling technique. The sample was divided into two groups. They were students who take English course program and those who do not.

\subsection{Hypothesis}

The hypothesis of this study can be formulated as follows:

1. Intensive English courses students and vocabulary mastery:

a. Ho: There is no a significance 
difference of English vocabulary mastery between students who take English courses and those who do not.

b. Ha: There is a significance difference of English vocabulary mastery between students who take English courses and those who do not

2. The effects of joining English courses towards students' vocabulary mastery.

\subsection{Techniques of Collecting Data}

In this study, the researcher did research online via Google Form for two steps. First, the researcher gave a test to the students. Second, the researcher gave a questionnaire to the students. The descriptions of the instruments that used in this study were as below:

1. Test

The researcher provided a multiplechoice form of English vocabulary mastery test for students. The test was conducted to measure and compare students' English vocabulary mastery between students who took English course program and those who do not. There were 40 questions. It focused on content words in terms of verb, noun, adjective, and adverb.

\section{Questionnaire}

The researcher provided two kinds of questionnaire about English course program and English learning activity. The English course program questionnaire was given to students who took English course program to answer the second research problem about the effects of students' participation in
English course program on their English vocabulary mastery. Whilst, The English learning activity questionnaire was given to students who did not took English course program and it was intended to inquire what activities or things that supported their English vocabulary learning.

\subsection{Techniques of Analyzing Data}

1. Test

The test was analyzed by descriptive and inferential analysis. In descriptive analysis, the researcher classified both students' answers, after that checked the correct students' answers, next gave a score of the students answer by multiplying the number of right answers by 2.5 . As a result, the students who got 40 points would get 100 scores. The researcher also gave score classifications of the students' answer which was adapted from Depdikbud (2005) cited in Jumiaty (2015).

Table 1. The Score Classification

\begin{tabular}{|c|c|}
\hline Score & Classification \\
\hline $9.6-10$ & Excellent \\
\hline $8.6-9.5$ & Very Good \\
\hline $7.6-8.5$ & Good \\
\hline $6.6-7.5$ & Fairly Good \\
\hline $5.6-6.5$ & Fair \\
\hline $3.6-5.5$ & Poor \\
\hline $0.0-3.5$ & Very Poor \\
\hline
\end{tabular}

Source: Analysis on Vocabulary Mastery between Female and Male Students of Junior High School (Andi Asri Jumiaty, 2015)

The result of the test was also analyzed into the SPSS 24 program by analyzing the frequency and the rate percentage of the students' score, median, mean, mode and 
standard deviation. The researcher also gave distribution of the frequency into histogram.

In inferential analysis, the researcher conducted a nonparametric test, namely Mann Whitney test. As Suyanto and Gio (2017, p.19) stated that the Mann-Whitney test is an alternative to the t-test for two independent populations when the population normality assumption is not met.

Based on the statement above, the researcher conducted a normality test first. Then, the researcher tested the hypothesis by conducting the Mann Whitney test.

\section{Questionnaire}

There were several steps to analyze the data through SPSS 24:

1. Identify the result of students' responses.

2. Categorize and classify students' responses.

3. Give scores to students' responses.

4. Analyze the frequency and percentage of students' responses.

5. Describe students' responses of each item.

6. Analyze the conclusion.

The researcher analyzed the conclusion used a formula from Sudjana (2001, p. 129) in Muldyagin (2018). The formula was as follow:

\section{$\mathrm{P}=\mathbf{f} / \mathrm{N} \times 100 \%$}

After finding the result of the formula, the researcher can interpret the result with the table below:
Table 2. Interpretation Criteria Percentage

\begin{tabular}{|c|c|}
\hline Scale & Categories \\
\hline $20 \%-36 \%$ & Very low / worse \\
$36,01 \%-52 \%$ & Low / bad \\
$52,01 \%-68 \%$ & Highly Sufficient / Fair \\
$69.01 \%-84 \%$ & High/ good \\
$84.01 \%-100 \%$ & Very High / Very Good \\
\hline
\end{tabular}

Source: Narimawati (2007, p.85) inMuldyagin (2018).

\section{RESULT}

\subsection{Analysis of English Vocabulary Mastery Test}

1. Descriptive Analysis

The description of content words in

English vocabulary mastery test as follow:

Table 3. The Result of English Vocabulary Mastery Test Distribution

\begin{tabular}{|c|c|}
\hline Items & $\begin{array}{c}\text { Percentage } \\
(\%)\end{array}$ \\
\hline Noun & 82 \\
\hline Verb & 66 \\
\hline Adjective & 72 \\
\hline Adverb & 60 \\
\hline
\end{tabular}

From the result above, it can be seen the result of students' knowledge in content words in terms of noun, verb, adjective, and adverb. The result of noun item was $82 \%$; verb was $66 \%$; adjective was $72 \%$, and adverb was $60 \%$. The result shows that the students understand noun terms well.

After tabulating the percentage of content words, the researcher categorized the 
score classifications and analyzed the frequency and the rate percentage of the students' scores, median, mean, mode, and standard deviation as table follow:

a. Students' scores classification, frequency and rate percentage

Figure 1. Histogram of Students' Scores Classification, Frequency and Rate Percentage

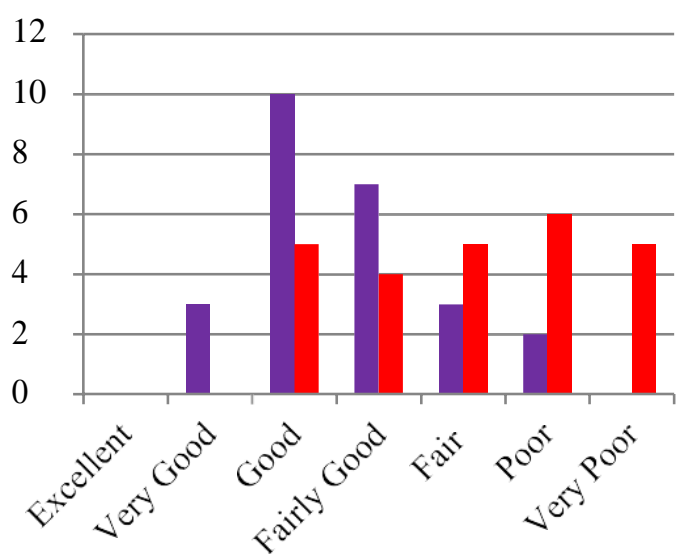

- Students take courses Students do

not take course

There were no students both students who take English course program and those who do not got excellent $(0 \%)$. From course table, there were 3 students (12\%) in very good category; 10 students (40\%) students in good category; 7 students $(28 \%)$ in fairly good category; 3 students (12\%) in fair category; 2 students (8\%) in poor category and there were no students $(0 \%)$ in very poor category.

Furthermore, there were no students $(0 \%)$ in very good category; 5 students $(20 \%)$ in good category; 4 students $(16 \%)$ in fairly good category; 5 students $(20 \%)$ in fair category; 6 students $(24 \%)$ in poor category, and 5 students $(20 \%)$ in very poor category. b. Students' median, mean, mode and std. deviation on English vocabulary mastery test

Table 4. Students' Median,Mean, Mode, and Standard Deviation on English Vocabulary Mastery

\begin{tabular}{|c|c|c|c|c|}
\hline Students & Median & Mean & Mode & Std. D \\
\hline A & 80.00 & 74.84 & 80.00 & 11,746 \\
\hline B & 57.00 & 56.60 & 32.00 & 17.825 \\
\hline
\end{tabular}

For students who take English course program (A), the median was 80.00, mean was 74.84 , mode was 80.00 , and standard deviation was 11.746. For students who do not take courses (B), it shows that the median was 57.00, the mean was 56.60, and mode was 32.00 and standard deviation was 17.825 .

\section{Inferential Analysis}

This analysis presents the result of a series of tests in order to prove the hypothesis in this study. The tests were the normality test and Mann Whitney test. The following is the elaboration of the results of the normality test and Mann Whitney test:

a. The result of normality test

Table 5. The Result of Normality Test

\begin{tabular}{|c|c|c|c|}
\hline \multirow{2}{*}{ Students } & \multicolumn{3}{|c|}{ Shapiro Wilk } \\
\cline { 2 - 4 } & Statistic & Df & Sig. \\
\hline A & .919 & 25 & 0.48 \\
\hline B & .921 & 25 & 0.54 \\
\hline
\end{tabular}

The test of normality used in this study was Shapiro-Wilk. The statistic value of students who take English course program 
was 0.919 , and the statistic value of students who do not take English course program was 0.921. Meanwhile, the sig value of students who take English course program was 0.48 . Then, the sig value of students who do not take English course program was 0.54 .

Based on the table 7 above, this data was not normally distributed because sig values of students who take English course program were 0.48 , which was $<0.05$. Under this condition, the Mann Whitney as the non- parametric test is suitable to measure the hypothesis in this study.

b. The result of Mann Whitney Test

Table 6. Students' Mean Rank

\begin{tabular}{|c|c|c|c|}
\hline Students & N & $\begin{array}{c}\text { Mean } \\
\text { Rank }\end{array}$ & $\begin{array}{c}\text { Sum of } \\
\text { Ranks }\end{array}$ \\
\hline A & 25 & 33.04 & 826.00 \\
\hline B & 25 & 17.96 & 449.00 \\
\hline
\end{tabular}

Based on the table above, it shows the mean rank of both group students. The mean rank of students who took English course program was higher than those who do not by 33.04 and 17.96 .

\section{Figure 2. The Result of Mann Whitney Test Test Statistics ${ }^{\mathrm{a}}$}

\begin{tabular}{lr} 
& \multicolumn{1}{c}{$\begin{array}{l}\text { Vocabular } \\
\text { y Mastery } \\
\text { Test }\end{array}$} \\
\hline Mann-Whitney U & 124.000 \\
\hline Wilcoxon W & 449.000 \\
\hline$Z$ & -3.665 \\
\hline $\begin{array}{l}\text { Asymp. Sig. (2- } \\
\text { tailed) }\end{array}$ & .000 \\
\hline
\end{tabular}

a. Grouping Variable: Students
Based on Table 9 above, the $U$ value was 124 and $\mathrm{W}$ value was 449 . The $\mathrm{Z}$ value value

-3.665. The Asymp sig. (2-tailed) value was 0.00 . It indicates that the value was $<0.05$. It was concluded that the $\mathrm{Ha}$ was accepted and Ho was rejected.

\subsection{Analysis of Questionnaire}

\subsubsection{English Course Program}

1. There were 9 students (36\%) in advance level; 7 students (28\%) in conversation level; 2 students $(8 \%)$ in intermediate 3 level; 2 students (8\%) in intermediate 2 level; 4 students (16\%) in intermediate 1 level, and 1 student (4\%) in elementary 3 levels. It can be seen that the most students joined the courses program in advance level.

2. There were 2 students (8\%) learning English in 6 months; 2 students (8\%) learning English in 1 year; 5 students (20\%) learning English in 1,5 years; 3 students (12\%) learning English in 2 years; 4 students (16\%) learning English in 2,5 years; 1 students (4\%) learning English in 3,5 years; 3 students (12\%) learning English in 4 years; 2 students (8\%) learning English in 4,5 years and 3 students (12\%) learning English in 5 years.

3. There was 1 student (4\%) learning English at course program in order to get a job easily; 1 student (4\%) being invited by friends and English is a difficult subject; 1 student (4\%) registered by parents to deepen English 
vocabulary; 1 student (4\%) registered by parents and want to make new friends; 2 students (8\%) stated English is very important, especially in getting work; 7 students (28\%) wanted to improve their English skills; 2 students (8\%) wanted to improve their English skills and get good score; 2 students (8\%) wanted to improve their vocabulary skills; 1 student (4\%) loved studying English; 1 student (4\%) loved studying English and stated English is important.; 4 students (16\%) loved studying English and wanted to improve English skills; 1 student (4\%) loved studying English and wanted to go abroad, and 1 student (4\%) loved studying English, especially reading and wanted to pass the national exam.

4. There was 1 student(4\%) liked studying in group and doing presentation; 1 student (4\%) liked studying in class; 1 student (4\%) liked playing game and studying; 3 students (12\%) liked playing game; 2 students (8\%) liked playing game and reading; 1 student (4\%) liked playing game and doing group assignment; 1 student (4\%) liked playing game and watching film; 1 student (4\%) liked singing; 1 student (4\%) liked singing and writing; 2 students (8\%) liked reading English text; 1 student (4\%) reading story and listening the tutor's explanation; 1 student (4\%) liked reading and discussion; 1 student (4\%) liked reading and watching film; 1 student
(4\%) liked reading English material; 1 student (4\%) liked reading, playing, and presentation; 1 student (4\%) liked listening music; 2 students (8\%) liked watching film; 1 student (4\%) liked watching film and playing games; 1 student (4\%) liked watching film and speaking, and 1 student (4\%) liked presenting group presentation and playing game.

5. As much as $52 \%$ of students responded strongly agree and $40 \%$ of students responded agree. This question can be interpreted that discipline in learning English by attending the class according to the schedule was a positive action that revealed their interest and enthusiasm attitude in learning. In addition, based on question 1, there were $2(8 \%)$ of students responded disagree which meant the students did not attend the course on schedule.

6. There were $15(60 \%)$ of students responded strongly agree and $9(36 \%)$ of students responded agree. In addition, there was only $1(4 \%)$ of students responded disagree because he/she thought that he/she did not really pay attention to the tutor's explanation.

7. There were 7 (28\%) of students responded strongly agree; $10(40 \%)$ of students responded agree; 6 (24\%) of students responded disagree, and 2 (8\%) of students responded strongly disagree. Nevertheless, the most students gave positive responses that they reviewed their English lesson at 
home.

8. There were $15(60 \%)$ of students responded strongly agree and 10 (40\%) of students responded agree. Thisquestion was interpreted that all of the students agreed that they were actively involved in the classroom by asking the tutor when they were confused in English lesson.

9. There were $16(64 \%)$ of students responded strongly agree, and 6 (24\%) of students responded agree. The students thought that they have always been serious about studying English could help them to get good grades. In addition, 3 (12\%) of students responded disagree. They thought they disagree that they have always been serious to study English in order to get good grades.

10. There were $19(76 \%)$ of students responded strongly agree and $6(24 \%)$ of students responded agree. Thus, all of the students showed positive responses that the course program improved their learning outcome at school.

11. There were $19(76 \%)$ of students responded strongly agree and $6(24 \%)$ of students responded agree. It indicated students' opinions that by joining English course program could help them to improve their vocabulary mastery.

12. There were $19(76 \%)$ of students responded strongly agree and $6(24 \%)$ of students responded agree. It indicated students' opinions that by joining English course program could help them to finish their English assignment better.

13. There were $14(56 \%)$ of students responded strongly agree and 11 (44\%) of students responded agree. Apparently, the course program provided a good teaching method by giving tips and tricks to support students' vocabulary mastery.

14. There were $15(60 \%)$ of students responded strongly agree and 10 $(40 \%)$ of students responded agree. These questions can be interpreted that students felt an improvement on their vocabulary learning. Therefore, the students could use their English vocabulary better after joining the course program.

15. There were $15(60 \%)$ of students responded strongly agree and 10 $(40 \%)$ of students responded agree. These questions could be interpreted that the students felt more motivated to master their English vocabulary after joining the course program.

16. There were $19(76 \%)$ of students responded strongly agree and $6(24 \%)$ of students responded agree. The students argued that they had good facilities and media to support their learning process in class.

17. There were 19 (76\%) of students responded strongly agree and 6 (24\%) of students responded agree. All of the students perceived that their tutor used 
various methods which supported them to understand English lessons.

18. There were $20(80 \%)$ of students responded strongly agree and $5(20 \%)$ of students responded agree. The students perceived that their tutor was very concerned over their vocabulary mastery.

19. There were $20(80 \%)$ of students responded strongly agree and 5 (20\%) of students responded agree. The students perceived that their tutor was very helpful over their vocabulary mastery.

20. There were $21(84 \%)$ of students responded strongly agree and $4(16 \%)$ of student responded agree. It can be assumed that the course program environment requires students to speak English. Thus, students practiced their English every day.

\subsubsection{English Learning Activity}

There were $5(20 \%)$ of students stated only study English at school; 2 (8\%) of students stated study English at school and listen music; 1 (4\%) of students stated reading English book and studying from YouTube; 2 (8\%) of students stated study at home; $3(12 \%)$ of students stated playing game; 1 (4\%) of student stated playing game and studying at home; 1 (4\%) of student stated reading English novel or article and watching film; 1 (4\%) of student stated only listening music; 1 (4\%) of student stated listening music and studying from application; $2(8 \%)$ of student stated that they joined English extracurricular; 1 (4\%) of student stated join extracurricular and study from YouTube or application; 2 (8\%) of student stated only watching film; 1 (4\%) of student stated watching film and listening music, and $2(8 \%)$ of student stated that they have joined English courses. From the table above, it can be seen most students did not study English by doing other supporting activities. However, they only studied English at school.

\section{CONCLUSION}

Based on the English vocabulary mastery test analysis above, the researcher found that the Asymp sig. (2-tailed) value is 0.00 . It indicates that the value is $<0.05$. It can be concluded that statistically there is a significant difference of English vocabulary mastery between students who take English courses and those who do not.

Furthermore, from the result of questionnaire analysis, the researcher found that the $\mathrm{p}$ value is $90.625 \%$ which was in veryhigh category. It indicates there are any effects of participating English Course Program on students' vocabulary mastery. 


\section{REFERENCES}

Andriani, D., \& Sriwahyuningsih, V. (2019). An analysis of students' mastery of vocabulary: at english department of universitas putra indonesia yptk padang at 2018/2019 academic year. ELTLectura, 6(2), 169-176.

Anisa, Ike. (2011). Improving students' vocabulary mastery using experential learning (a classroom action research on the sixth grade of $s d n$ banaran 01 in the academic year of 2009/2010). Surakarta: Sebelas Maret University.

Apriliyanti. (2019). Improving the students' understanding vocabulary meaning of descriptive texts through context clues strategy. Jurnal Pendidikan dan Pembelajaran Khatulistiwa,8 (9), 1-11.

Cambridge Dictionary. (n.d.). English course meaning. Retrieved from https://dictionary.cambridge.org/di cti onary/english/course. Accessed June 1, 2020.

Cohen, L., Manion, L., \& Morrison, K. (2018). Research methods in education. ( $8^{\text {th }}$ ed.). Routledge: NewYork

Hernawati. (2015). Buillding up the students' english vocabulary through fanny stories at smp negeri 2 duampanua kab.pinrang. Eternal (English, Teaching, Learning, and Research Journal), 1(2), 202-210.

Jumiaty, A. A. (2015). A comparative analysis on vocabulary mastery between female and male students of junior high school. ELITE (English and Literature Journal), 2(2), 158-167.

Muldyagin, D. H. (2018). The correlation between the interest in practicing english conversation and speaking fluency of english department students of pasundan university. Bandung: Pasundan University.

Schmitt, N. (2010). Researching vocabulary. a vocabulary research manual.Palgrave Mcmillan: UK

Setiyono, Kukuh. (2016). The influence of joining english course program on $11^{\text {th }}$ grade student achievement of sma muhammadiyah 1 purwokerto. Retrieved from http://repository.ump.ac.id/989. Accessed May 21, 2020.

Sugara, Roby. (2018). The comparison of students' vocabulary achievement by joining or not joining english club at state islamic university of north sumatera. Medan: Universitas Islam Negeri Sumatera Utara.

Susanto, Alpino. (2017). The teaching of vocabulary: a perspective. Jurnal KATA, 1(2), 182-191.

Suyanto, and Gio, PU. (2017). Statistika nonparametrik dengan spss, minitab, dan $r$. Usu Press: Medan.

Syaputri, Komala Dwi. (2015). The use of picto-textual glosses text in teaching vocabulary and reading toyoung learners (an experimental study at one of junior high school in desa sukaraja baru, palembang). Bandung: Indonesia University ofEducation. 